\title{
Differential induction of allergy responses by low molecular weight wheat proteins from six wheat cultivars
}

\author{
Miju Cho ${ }^{1} \cdot$ Hyeri Lee $^{1} \cdot$ Min Hee Hwang ${ }^{1}$ - Young-Keun Cheong ${ }^{2}$. \\ Chon-Sik Kang ${ }^{2}$ Nam Taek Lee ${ }^{3} \cdot$ Namhyun Chung ${ }^{1}$
}

Received: 29 November 2016 / Accepted: 1 December 2016 / Published Online: 31 March 2017

(C) The Korean Society for Applied Biological Chemistry 2017

\begin{abstract}
Although wheat is a common staple food in the world, some people suffer from a variety of wheat allergies. For example, wheat-dependent exercise-induced anaphylaxis is induced in the gastrointestinal tract by wheat proteins. Relatively high molecular weight proteins that are salt-insoluble induce many wheat allergies. In the present study, we investigated the induction of an allergy response using crude wheat proteins, which are relatively low molecular weight, salt-soluble proteins. The crude antigen used in this study was extracted using phosphate buffered saline. When the antigen extracts from various wheat cultivars were orally administered, differentiable degrees of allergy responses were observed as measured by serum IgE and histamine secretion compared to the control. Serum IgE levels increased following administration of three of the wheat extracts. This evidence suggests that a combination of salt-soluble wheat proteins could be antigens for the induction of various allergy responses.
\end{abstract}

Keywords Crude antigen - Low MW wheat protein - Serum histamine $\cdot$ Serum $\operatorname{IgE} \cdot$ Wheat allergy $\cdot$ Wheat cultivar

Miju Cho, Hyeri Lee, and Min Hee Hwang contributed equally to this study.

Nam Taek Lee $(\bowtie)$

E-mail:ntlee@korea.ac.kr

Namhyun Chung $(\bowtie)$

E-mail: nchung@korea.ac.kr

${ }^{1}$ Department of Biosystems Engineering, College of Life Sciences and Biotechnology, Korea University, Seoul 02841, Republic of Korea

${ }^{2}$ National Institute of Crop Science, RDA, Wanju 55365, Republic of Korea

${ }^{3}$ Functional Food Research Center, College of Life Sciences and Biotechnology, Korea University, Seoul 02841, Republic of Korea

This is an Open Access article distributed under the terms of the Creative Commons Attribution Non-Commercial License (http://creativecommons. org/licenses/by-nc/3.0/) which permits unrestricted non-commercial use, distribution, and reproduction in any medium, provided the original work is properly cited.

\section{Introduction}

Approximately 10,000 years ago, wheat cultivation began (Shewry 2009). Now, it is one of the most popular cereal grains. Wheat constituted $41 \%$ of all cereal calories consumed between 20052009 (Shiferaw et al. 2013). Although wheat is a staple food in many countries, in a subset of people, it causes allergic hypersensitivity including wheat-dependent exercise-induced anaphylaxis (WDEIA), atopic eczema/dermatitis syndrome, and baker's asthma (Gómez et al. 1990; Battais et al. 2005).

WDEIA affects a subset of the population performing physical activity after ingesting wheat. Antigens for WDEIA go through the gastrointestinal track and cause severe symptoms in the body, especially the gastrointestinal, cardiovascular, urticarial, and respiratory systems (Hofmann et al. 2012). A few years ago, omega-5 gliadin in wheat was identified as the cause of WDEIA (Palosuo et al. 1999; Morita et al. 2003; Morita et al. 2009). Wheat proteins are divided into salt-soluble proteins and glutens, which include glutenins and gliadins such as omega-5 gliadin (Morita et al. 2009). In the present study, we compared the level of allergy response induced by orally administered crude antigens from six wheat cultivars. These six wheat cultivars varied in their origin, wheat type, and cultivation year. Crude antigens were extracted using phosphate buffered saline (PBS) and used to compare the induction levels of allergic responses.

\section{Materials and Methods}

\section{Crude antigen extract}

Crude antigens were extracted using the method of Shin et al. (2003). Lipids were removed from $50 \mathrm{~mL}$ of ground wheat using $100 \mathrm{~mL}$ of ether. After incubation at room temperature for $1 \mathrm{~min}$, the samples were centrifuged and the supernatants were discarded. The remaining ether in the pellet was evaporated through intermittent stirring overnight with an open cap. The dried pellets were suspended 
in $350 \mathrm{~mL}$ phosphate buffered saline. Then, the suspended mixture was agitated vigorously overnight at $4{ }^{\circ} \mathrm{C}$ and was centrifuged at $10,000 \times g$ for $1 \mathrm{~h}$ at $4{ }^{\circ} \mathrm{C}$. The supernatants were filtered using a $3 \mathrm{kDa}$ centrifugal filter (Merck Millipore Inc., Darmstadt, Germany) and the proteins on the centrifugal filter were suspended with distilled water. These aqueous mixtures were lyophilized for 3 days and kept at $-80{ }^{\circ} \mathrm{C}$.

\section{SDS-PAGE}

Sodium dodecyl sulfate polyacrylamide gel electrophoresis (SDSPAGE) was employed to visualize crude antigens. First, the extracted samples were dissolved in distilled water at a concentration of 5 $\mathrm{mg} / \mathrm{mL}$ and mixed with $2 \times$ Laemmli sample buffer (Bio-Rad, Hercules, California, USA) containing $5 \% \beta$-mercaptoethanol. The mixture was denatured at $99^{\circ} \mathrm{C}$ for $10 \mathrm{~min}$ and loaded onto a $10 \%$ polyacrylamide gel. The amount of loaded protein was 10 $\mu \mathrm{g}$ per well, which was quantified using the Pierce BCA protein assay kit (Thermo Fisher Scientific, Waltham, Massachusetts, USA). Tris-glycine buffer ( $\mathrm{pH} 8.3$ ) was used as the running buffer, and the gel was initially run at $80 \mathrm{~V}$ for $30 \mathrm{~min}$ and then at $120 \mathrm{~V}$ for $120 \mathrm{~min}$. Coomassie brilliant blue staining allowed visualization of the proteins in the gel.

\section{Animals}

Nine-week-old male C3H/HeJ mice (Japan SLC, Hamamatsu, Japan) were sensitized with crude antigens from six different varieties of wheat. The mice were housed at $22{ }^{\circ} \mathrm{C}, 50 \%$ humidity, and a 12/12 h light/dark cycle. The mice were fed a standard diet with continuous free access to water bottles and divided into 8 groups: negative control, positive control, and treatment with the six different wheat extracts. The animals were orally sensitized with a mixture of aluminum potassium sulfate (Sigma-Aldrich Chemicals, St. Louis, Missouri, USA) (1 mg) and crude antigen $(5 \mathrm{mg})$ at days $1,2,3,7$, and 21 . The mixtures were made by dissolving aluminum potassium sulfate and crude antigen in distilled water. For the positive control, mice were orally sensitized with aluminum potassium sulfate $(1 \mathrm{mg})$. After 28 days, the mice were sacrificed to collect blood from the inferior vena cava. Then, the collected blood was centrifuged at $12,000 \times g$ $\left(4{ }^{\circ} \mathrm{C}\right)$ for $10 \mathrm{~min}$ to obtain the serum, which was used for the evaluation of histamine and $\operatorname{IgE}$ concentrations. Korea University Institutional Animal Care and Use Committee approved all experimental procedures for the animals.

\section{Enzyme-linked immunosorbent assay (ELISA)}

IgE in the mouse serum was evaluated using mouse IgE ELISA Ready-SET-Go kit (Affymetrix, Waltham, Massachusetts, USA) following the manufacturer's instructions. Histamines in the mouse serum were measured with a histamine ELISA kit (Enzo Life Science, Farmingdale, New York, USA) following the manufacturer's instructions.

\section{Results and Discussion}

\section{Wheat protein analysis by SDS-PAGE}

The six wheat cultivars are different in their origin, type, and cultivation year. Wheat type refers to the classification of wheat cultivars into hard and soft wheats according to protein content. Hard wheat contains a high percentage of protein (10 to $14 \%$ ) whereas soft wheat contains a low percentage of protein (8 to 11 $\%$ ) (Delcour et al. 2012). The wheat cultivars used are as follows: hard red winter wheat (HRW), Australian hard wheat (AH), Iksan Goso soft wheat (IGSW), and Gyeongnam Jokyung wheat (GJW) cultivated in 2014, and Australian standard white wheat (ASW) as well as Gwangju Kumkang wheat (GKW) cultivated in 2015 (Table 1). ASW and GKW are medium protein wheats.

Wheat proteins are composed of non-gluten proteins, which encompass 15 to $20 \%$ of the total protein, and gluten proteins, which constitute the remaining proteins (Veraverbeke and Delcour 2002). Non-gluten proteins are typically salt-soluble and the major components are albumin and globulin, which range in size from 15 to $100 \mathrm{kDa}$ (Kozai et al. 2006). Gluten proteins include gliadins and glutenins and are salt-insoluble proteins. Gliadins typically are extracted with alcohol and glutenins are soluble in alkali solutions (Kozai et al. 2006). The size of gliadins is between 33 and $67 \mathrm{kDa}$ and that of glutenins is between 75 and $110 \mathrm{kDa}$ (Battais et al. 2003; Kim et al. 2016). Among gliadins, the size of omega-5 gliadin, which is a major inducer of WDEIA, is between 50 and $67 \mathrm{kDa}$ (Comino et al. 2012). By considering the characteristics of wheat proteins, we suggest that crude antigens extracted with PBS mostly include salt-soluble proteins; that is, non-gluten proteins. As shown in Fig. 1, few proteins larger than $75 \mathrm{kDa}$ were obtained. This result indicates that the crude antigen extracts did not contain

Table 1 The six types of wheat cultivars used in the study*

\begin{tabular}{|c|c|c|c|c|}
\hline Year & Abbreviation & Name of wheat & Origin & Wheat type \\
\hline \multirow{4}{*}{2014} & HRW & Hard red winter wheat & America & Hard Wheat \\
\hline & $\mathrm{AH}$ & Australian hard wheat & Australia & Hard Wheat \\
\hline & IGSW & Iksan Goso soft wheat & Republic of Korea & Soft Wheat \\
\hline & GJW & Gyeongnam Jokyung wheat & Republic of Korea & Soft Wheat \\
\hline \multirow{2}{*}{2015} & ASW & Australian standard white wheat & Australia & Medium Wheat \\
\hline & GKW & Gwangju Kumkang wheat & Republic of Korea & Medium Wheat \\
\hline
\end{tabular}

*The wheat originated from America, Australia, or Korea. Wheat type is associated with protein content 


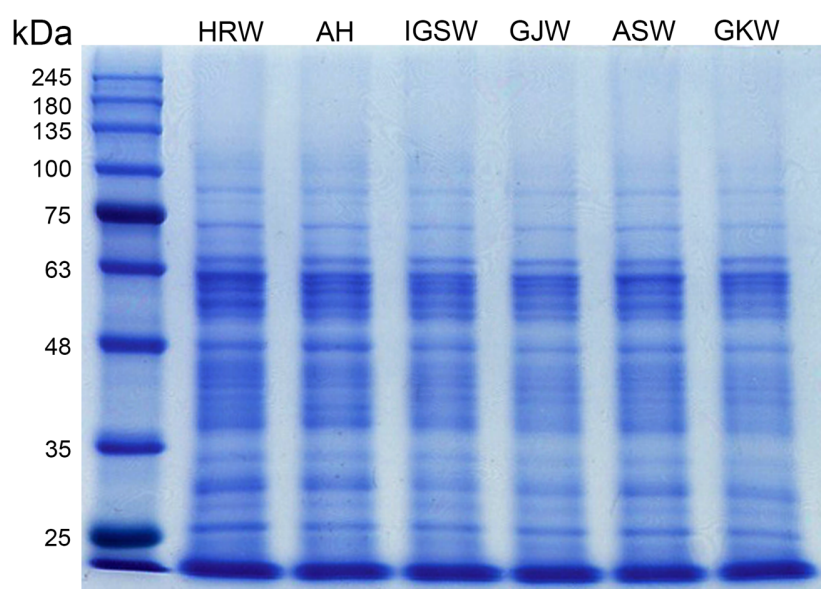

Fig. 1 SDS-PAGE of crude wheat antigens. Coomassie brilliant blue staining of proteins from hard red winter wheat (HRW), Australian hard wheat (AH), Iksan Goso soft wheat (IGSW), Gyeongnam Jokyung wheat (GJW), Australian standard white wheat (ASW), and Gwangju Kumkang wheat (GKW) are shown. BLUeye pre-stained protein ladder (GeneDirex Inc., Taiwan) was used to mark the protein sizes

glutenins (75 to $110 \mathrm{kDa}$ ). In addition, alcohol-soluble gliadins were not included in the crude antigen extracts. Gliadins are a major cause of WDEIA and glutenins also are implicated in WDEIA, although to a lesser extent (Kozai et al. 2006). However, in the present study, we used the salt-soluble proteins to sensitize mice and found induction of allergy responses.

\section{Analysis of IgE and histamine by ELISA}

Histamine and $\operatorname{IgE}$ are significant factors in allergy reactions. Histamine is secreted by mast cells or basophils causing many different allergy symptoms. Many patients threatened by various degrees of allergenic responses have elevated levels of histamine (Lin et al. 2000). When IgE is activated by specific allergens and attaches to the Fce receptor on mast cells or basophils, it acts as a trigger for histamine release. Aluminum potassium sulfate was used as an adjuvant that promotes an immune response by stimulating the immune system or prolonging existence of the antigen. Aluminum potassium sulfate induces antigen precipitation, which provides the immune system with longer exposure to the antigen to mount an increased immune response (HogenEsch
2002; Marrack et al. 2009).

We checked body weight and food intake once every 3 days during the experimental period (Table 2). Because body weight and food intake reflect the condition of the animals, these results show the health of the animals. No statistical difference was found between the initial and final body weight, body weight gain, or food intake among tested groups. Thus, the condition of the mice most likely did not influence the results obtained in this experiment.

The IgE concentrations in mouse blood induced in response to the six different wheat cultivars were not statistically different compared to the negative control via ELISA analysis. However, the IgE concentrations for HRW and ASW ( $p$-value of 0.01 ) as well as AH ( $p$-value of 0.05 ) increased significantly compared to the positive control, which was treated with aluminum potassium sulfate (Fig. 2A). These three wheat cultivars as well as GKW are hard or medium wheats, suggesting that the amount of protein in wheat could have a significant effect on $\operatorname{IgE}$ induction and possibly allergy induction. The hard wheats employed in this study have higher protein content than the soft wheats as described above. In Fig. 2A, the negative control group had no treatment and the positive control group was treated with aluminum potassium sulfate. However, unexpectedly, no statistical difference was observed between the negative and positive control. This might mean that the treatment of aluminum potassium sulfate in the positive control did not induce any hypersensitivity or immune response. Thus, in this experimental condition, the role of aluminum potassium sulfate to prolong the antigen was diminished and it did not sufficiently stimulate the immune system to a detectable difference.

Based on the ELISA analysis of IgE in Fig. 2A, an additional histamine ELISA was analyzed with the serum from the mice treated with IGSW and GJW cultivars. These cultivars induced relatively low concentrations of $\mathrm{IgE}$ secretion and thus were expected to induce low levels of histamine secretion (Fig. 2B). There was no statistical difference in the concentration of serum histamine between the positive control, IGSW, and GJW. However, the histamine concentration of the IGSW and GJW groups were higher than that of the negative control. This result indicates that these two wheat cultivars might induce lower histamine secretion as well as IgE secretion.

Table 2 Body weight and food intake of each group treated with different wheat cultivars*

\begin{tabular}{|c|c|c|c|c|c|c|c|c|}
\hline Mean \pm SD & Con & + Con & HRW & $\mathrm{AH}$ & IGSW & GJW & ASW & GKW \\
\hline Initial weight (g) & $20.41 \pm 0.42$ & $20.00 \pm 0.90$ & $19.85 \pm 1.06$ & $19.56 \pm 0.95$ & $19.82 \pm 1.33$ & $19.82 \pm 0.96$ & $19.12 \pm 1.03$ & $19.59 \pm 0.89$ \\
\hline Final weight (g) & $21.75 \pm 0.32$ & $21.12 \pm 1.25$ & $20.78 \pm 0.96$ & $20.30 \pm 0.86$ & $20.95 \pm 1.14$ & $20.89 \pm 1.16$ & $20.53 \pm 0.94$ & $21.09 \pm 1.60$ \\
\hline Body weight gain (g) & $5.94 \pm 2.25$ & $5.40 \pm 2.27$ & $3.60 \pm 3.92$ & $1.22 \pm 2.26$ & $4.47 \pm 2.76$ & $4.25 \pm 1.09$ & $2.69 \pm 2.74$ & $5.34 \pm 4.59$ \\
\hline Food Intake (g/day) & $2.58 \pm 0.28$ & $2.73 \pm 0.23$ & $0.23 \pm 0.32$ & $2.97 \pm 0.41$ & $3.06 \pm 0.42$ & $2.77 \pm 0.27$ & $2.95 \pm 0.38$ & $3.02 \pm 0.25$ \\
\hline
\end{tabular}

*The values in the table are expressed as mean value and standard deviation. There was no statistical difference between the groups. Con is the negative control; + Con is the positive control, which received aluminum potassium sulfate $(1 \mathrm{mg})$; each experimental groups were treated with aluminum potassium sulfate $(1 \mathrm{mg})$ and crude antigen $(5 \mathrm{mg})$. Wheat varieties include hard red winter wheat (HRW), Australian hard wheat (AH), Iksan Goso soft wheat (IGSW), Gyeongnam Jokyung wheat (GJW), Australian standard white wheat (ASW), and Gwangju Kumkang wheat $(\mathrm{GKW})$ 

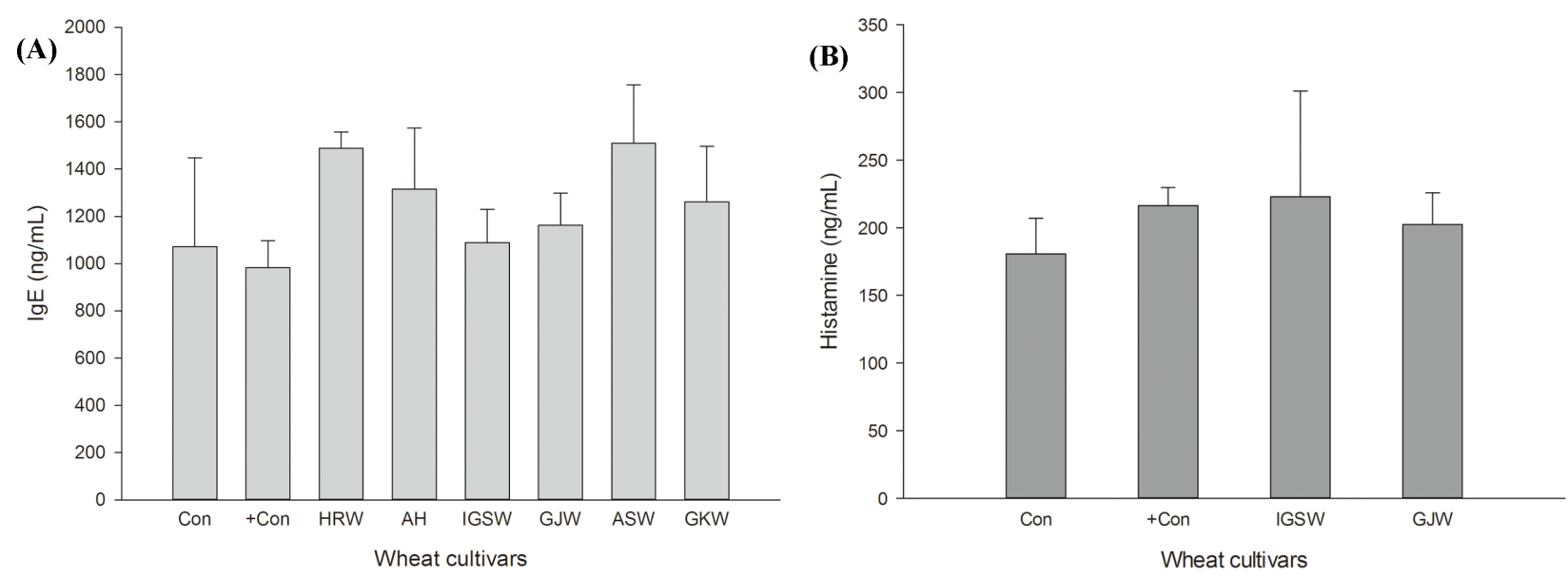

Fig. 2 ELISA analysis for the determination of IgE and histamine concentrations in mouse blood samples. The mice were treated with crude antigens from six wheat cultivars. IgE levels in HRW and ASW $(p<0.01)$ and AH $(p<0.05)$ increased significantly compared to the positive control (A). ELISA analysis for histamine concentrations of IGSW and GJW showed no statistically significant differences compared to controls (B). Negative control (Con), positive control (+Con), hard red winter wheat (HRW), Australian hard wheat (AH), Iksan Goso soft wheat (IGSW), Gyeongnam Jokyung wheat (GJW), Australian standard white wheat (ASW), and Gwangju Kumkang wheat (GKW)

In this study, we have compared the levels of allergy response induction after administration of the crude antigen extract of different wheat cultivars by IgE level. IgE is one of the signature factors of hypersensitivity and is utilized for specific allergy tests (Asero et al. 2007). However, our current results show that the levels of serum $\operatorname{IgE}$ and serum histamine are not equivalent, suggesting there could be another variable that modulates the interaction between IgE and histamine secretion.

In future studies, the quantity of allergy inducible proteins in whole wheat needs to be considered, including whether they are gluten or non-gluten proteins. In this study, salt-soluble proteins were extracted from various wheat cultivars. The differential allergy responses observed for IgE and histamine secretion showed that the salt-soluble wheat proteins also could be involved in inducing allergy responses, especially in hard wheat containing a high concentration of protein. Although the protein component is a major factor in inducing allergy responses, the other components in wheat extracts might be involved in the phenomenon observed in our results. Additional studies with other wheat cultivars are needed to ensure that the results in this study are a general phenomenon with wheat.

Acknowledgments This work was supported by a grant (PJ010529) from the National Institute of Crop Science, Rural Development Administration, Republic of Korea.

\section{References}

Asero R, Ballmer-Weber BK, Beyer K, Conti A, Dubakiene R, FernandezRivas M, Hoffmann-Sommergruber K, Lidholm J, Mustakov T, Oude Elberink JN, Pumphrey RS, Stahl Skov P, van Ree R, Vlieg-Boerstra BJ, Hiller R, Hourihane JO, Kowalski M, Papadopoulos NG, Wal JM, Mills EN, Vieths S (2007) IgE-mediated food allergy diagnosis: Current status and new perspectives. Mol Nutr Food Res 51: 135-147 doi:10.1002/ mnfr.200600132

Battais F, Mothes T, Moneret-Vautrin DA, Pineau F, Kanny G, Popineau Y, Bodinier M, Denery-Papini S (2005) Identification of IgE-binding epitopes on gliadins for patients with food allergy to wheat. Allergy 60: 815-821 doi:10.1111/j.1398-9995.2005.00795.x

Battais F, Pineau F, Popineau Y, Aparicio C, Kanny G, Guerin L, MoneretVautrin DA, Denery-Papini S (2003) Food allergy to wheat: identification of immunogloglin $\mathrm{E}$ and immunoglobulin $\mathrm{G}$ binding proteins with sequential extracts and purified proteins from wheat flour. Clin Exp Allergy 33: 962-970

Comino I, Real A, Vivas S, Siglez MA, Caminero A, Nistal E, Casqueiro J, Rodriguez-Herrera A, Cebolla A, Sousa C (2012) Monitoring of glutenfree diet compliance in celiac patients by assessment of gliadin 33-mer equivalent epitopes in feces. Am J Clin Nutr 95:670-677 doi:10.3945/ ajen.111.026708

Delcour JA, Joye IJ, Pareyt B, Wilderjans E, Brijs K, Lagrain B (2012) Wheat gluten functionality as a quality determinant in cereal-based food products. Annu Rev Food Sci Technol 3: 469-492 doi:10.1146/annurevfood-022811-101303

Gómez L, Martin E, Hernandez D, Sanchez-Monge R, Barber D, del Pozo V, Andres B, Armentia A, Lahoz C, Salcedo G, Palomino P (1990) Members of the á-amylase inhibitors family from wheat endosperm are major allergens associated with baker's asthma. FEBS Lett 261: 85-88

Hofmann SC, Fischer J, Eriksson C, Bengtsson Gref O, Biedermann T, Jakob $\mathrm{T}$ (2012) IgE detection to alpha/beta/gamma-gliadin and its clinical relevance in wheat-dependent exercise-induced anaphylaxis. Allergy 67: 1457-1460 doi:10.1111/all.12020

HogenEsch H (2002) Mechanisms of stimulation of the immune response by aluminum adjuvants. Vaccine 20: S34-S39

Kim JH, Pak PJ, Kim J-G, Cheong Y-K, Kang C-S, Lee NT, Chung N (2016) Comparison of Allergy-Inducible Wheat protein contents among imported and domestic wheat flours in Korea. J Appl Biol Chem 59: 1-3 doi:10.3839/jabc.2016.001

Kozai H, Yano H, Matsuda T, Kato Y (2006) Wheat-dependent exerciseinduced anaphylaxis in mice is caused by gliadin and glutenin treatments. Immunol Lett 102: 83-90 doi:10.1016/j.imlet.2005.07.007

Lin RY, Schwartz LB, Curry A, Pesola GR, Knight RJ, Lee HS, Bakalchuk L, Tenenbaum C, Westfal RE (2000) Histamine and tryptase levels in patients with acute allergic reactions: An emergency department-based 
study. J Allergy Clin Immunol 106: 65-71 doi:10.1067/mai.2000.107600

Marrack P, McKee AS, Munks MW (2009) Towards an understanding of the adjuvant action of aluminium. Nat Rev Immunol 9: 287-293 doi:10.1038/nri2510

Morita E, Matsuo H, Chinuki Y, Takahashi H, Dahlstrom J, Tanaka A (2009) Food-dependent exercise-induced anaphylaxis-importance of omega-5 gliadin and HMW-glutenin as causative antigens for wheat-dependent exercise-induced anaphylaxis. Allergol Int 58: 493-498 doi:10.2332/ allergolint.09-RAI-0125

Morita E, Matsuo H, Mihara S, Morimoto K, Savage AWJ, Tatham AS (2003) Fast $\omega$-gliadin is a major allergen in wheat-dependent exerciseinduced anaphylaxis. J Dermatol Sci 33: 99-104 doi:10.1016/s09231811(03)00156-7

Palosuo K, Alenius H, Varjonen E, Koivuluhta M, Mikkola J, Keskinen H,
Kalkkinen N, Reunala T (1999) A novel wheat gliadin as a cause of exercise-induced anaphylaxis. J Allergy Clin Immun 103: 912-917 Shewry PR (2009) Wheat. J Exp Bot 60: 1537-1553 doi:10.1093/jxb/erp058 Shiferaw B, Smale M, Braun H-J, Duveiller E, Reynolds M, Muricho G (2013) Crops that feed the world 10. Past successes and future challenges to the role played by wheat in global food security. Food Sec 5: 291-317 doi:10.1007/s12571-013-0263-y

Shin YS, Yo SH, Kim MC, Choi JH, Suh YJ, Suh CH, Nahm DH, Park HS (2003) A case of wheat-induced anaphylaxis in an adult. J Asthma Allergy Clin Immunol 23: 539-543

Veraverbeke WS, Delcour JA (2002) Wheat protein composition and properties of wheat glutenin in relation to breadmaking functionality. Crit Rev Food Sci Nutr 42: 179-208 doi:10.1080/10408690290825510 